\title{
THE REVIVAL OF THE TOURISM INDUSTRY FROM THE COVID-19 PANDEMIC DISASTER \\ Debashish Roy
}

Assistant Professor, Metropolitan University, Bangladesh.

Email: debashish@metrouni.edu.bd

Article History: Received on $12^{\text {th }}$ June 2021, Revised on $1^{\text {st }}$ July 2021, Published on $5^{\text {th }}$ July 2021

\begin{abstract}
Purpose of the study: COVID-19 pandemic has severely hit the global economy. It has also had a huge impact on the tourism industry. The purpose of the study is to identify the possible initiatives to be taken to revive the tourism industry during or after the COVID-19 era.
\end{abstract}

Methodology: A qualitative analysis of secondary data has been applied. NVivo 12 has been used for organizing, analyzing, and visualizing the data.

Main Findings: It is found that government will have to play the most prominent role in the revival of the tourism sector through financial stimulus packages and subsidies. The use of marketing activities, promotional tools, and social media platforms will also aid in the recovery process. Initially, tourism activities can be restarted at domestic levels and in travel bubbles, motivating international tourists. Most importantly, maintaining hygiene and maintaining social distance will be the main tool to revive the tourism industry.

Applications of this study: The findings of this study will enable the decision-makers of the hospitality and tourism industry to make a strategic recovery plan Covid-19 stricken tourism economy.

The originality of this study: Although most of the industries are slowly turning around during the pandemic, the tourism industry is still struggling to survive. This study proposes several possible recovery plans in light of past epidemic experiences.

Keywords: COVID-19, Pandemic, Revival, Tourism, Marketing Activities, Promotional Tools.

\section{INTRODUCTION}

The tourism and hospitality industry plays a significant role in the global economy. This industry had directly contributed 3.3\% of the total global GDP in 2019. However, the tourism industry's total contribution to global GDP is 10.4\% (Statista Research Department, 2021). The total contribution of the tourism industry in global GDP was 9,170 billion U.S. dollars in 2019 (World Travel and Tourism Council report, n.d.). Tourism sectors also played a vital role in employment generation. One out of four new jobs was created by the travel and tourism industry from 2014 to 2019. In 2019, 334 million jobs were offered in this industry (World Travel and Tourism Council report, n.d.). But the novel Coronavirus (COVID -19), which appeared in late 2019, has devastated this sector terribly.

Having started from Wuhan (a Chinese city) in December 2019, the coronavirus has affected 219 countries and territories around the globe. As of April 2021, the world has reported 147,182,092 confirmed coronavirus cases and a death toll of 3,115,356 (Worldometers, n.d.). Although the world is attacked by different viruses at different times (for instance, SARS, MARS, Ebola), such acute infections and deaths have not been seen in recent times. World Health Organization has compared the coronavirus pandemic to the influenza pandemic (also known as Spanish flu) of 1918. This horrific recent coronavirus pandemic is wreaking havoc on the global economy. Various countries and regions have introduced lockdowns to prevent infection. But as a result, these lockdowns, the economy has been severely affected. Lockdown causes people to lose jobs, businesses shut down, and huge numbers of people fall below the poverty line. Almost all industries in the world have been directly or indirectly affected by the coronavirus pandemic. The world's tourism industry is no exception to that. The activities of the global tourism industry have almost come to a standstill.

In 2020, about 62 million people lost their jobs in the tourism industry. While 334 million workers were involved in the tourism industry in 2019, that number dropped to 272 million in 2020 (a drop of 18.5\%). The tourism industry contributed $10.4 \%$ of the total GDP to the global economy in 2019, but in 2020 it stands at only $5.5 \%$. Spending from international visitors has been dropped by $69.4 \%$, whereas domestic visitors' spending was reduced by $45 \%$ (World Travel and Tourism Council report, n.d.). This is assumed to be severely affecting the survival of the global tourism industry.

Needless to say, the coronavirus pandemic is massively harming the tourism industry. It's been almost a year and a half since the virus was caught in December 2019 in China's Wuhan City. But the severity and extent of this coronavirus cannot be said to have gotten any better. Obstacles to movement and fear among the public have brought the tourism industry to a standstill. The objective of this study is to discuss what initiatives can be taken to revive the stagnant tourism industry. The study will also analyze the impact of the coronavirus pandemic in the tourism industry. 


\section{METHODOLOGY}

This is an exploratory study based on secondary data. Exploratory studies are usually conducted to develop insight and understanding on some phenomena. The secondary data has been collected from several online and offline sources using keyword search and Boolean operator techniques. A qualitative analysis of the gathered data has been performed to explore the possible recovery guideline for the pandemic-affected tourism industry. For qualitative analysis, firstly, data were arranged according to importance and relevancy. Secondly, the data were sorted according to similarity, and visual interpretation has been done. Finally, the meaning of the analyzed data has been interpreted to draw a conclusion.

\section{FINDINGS AND DISCUSSION}

\section{The impact of the epidemics on the tourism industry over the ages}

The global corona pandemic is not the first disaster to hit the tourism industry. There have been epidemics in the past, and their adverse effects on the tourism industry were severe. But every time the tourism industry goes to the edge of the abyss, it turns around. So those involved in the tourism industry are still hopeful that the global coronavirus pandemic will be over and that every tourist destination will be buzzing again with the noise of tourists.

The coronavirus pandemic, which is currently plaguing the global tourism industry, is being compared to the Spanish flu, also known as the influenza pandemic, which occurred in 1918-1920. About 500 million people worldwide were infected with the virus. However, since the tourism industry was not very developed, it was not possible to accurately determine the impact of the pandemic on the tourism industry (Menegaki, 2020). In the last couple of decades, the world tourism industry has been affected by several health crises like SARS, Ebola, MERS, Zika virus, Bird flu, etc. Severe Acute Respiratory Syndrome (SARS) was first appeared in February 2002 in China, and later, Hong Kong, Singapore, Viet Nam, and Canada were affected by the virus (Pine and McKercher, 2004). The epidemic showed a severe negative impact on the travel and tourism industry. According to World Tourism Organization, worldwide tourism arrival was declined by $1.2 \%$ to 694 million in 2003 due to the SARS outbreak. During the outbreak, 12 million travels booking was cancelled in Asia and the Pacific (Wilder-Smith, 2006). In 2009, H1N1 or Swine flu hit around 214 countries, causing 18,500 deaths (Menegaki, 2020), affecting the global tourism industry. Monterrubio (2010) found that the hotel, restaurant, and aviation industries were the most affected sector by swine flu. According to CAPA (2009), international airlines faced a $20 \%$ decline in revenue from passengers. MERS-CoV or Middle East Respiratory Syndrome was first reported in Saudi Arabia in September 2012 by health officials. But the largest MERS outbreak occurred in the Republic of Korea in 2015 (Centers for Disease Control and Prevention, 2019). According to the Korean Culture and Tourism Institute (2015), inbound tourists in Korea were 1.53 million less than the previous year. Similarly, epidemics like Bird flu or Avian influenza or H5N1 in 2017, Ebola in 2014, Zika virus in 2014 and 2016 have also shown a significant adverse effect on the tourism industry worldwide.

\section{Impact of COVID-19 pandemic on the tourism industry}

The global tourism industry is based on the free mobility of people, but the COVID-19 pandemic has directly stopped the mobility of people and thus the tourism industry (Guridno and Guridno, 2020). Sheller (2020) mentioned in this regard that "all human motilities have been brought to an abrupt halt." As COVID-19 is an infectious disease, governments of different countries have enforced laws to restrict the physical mobility of people. The term "social distancing" has been introduced at the social level to protect against the spread of the virus. However, such concepts, like, social distance and restricted physical mobility, do not support the humble nature of hospitality and tourism (Long, 2020). In a study in China, Hoque et al. (2020) found that the Coronavirus has contributed a significant impact on the global tourism industry. People feel risky to mix up with Chinese people, and thus global tourists have cancelled their schedule to visit China. Moreover, Chinese tourists have also been banned in several countries. Many countries have also adjourned trade and travel relationships with China (Aljazeera, 2020).

Any infectious epidemic has both direct and indirect effects on the economy, health sector as well as other government sectors. Such an epidemic may limit agriculture, food production, transportation, and manufacturing. Besides that, the reduced economic activities may lead to a high cost of food items, transportation, and service, which will cause poor tourist satisfaction (Schulze \& Wansink, 2012). After the COVID-19 outbreak, people are restricted from doing their work from home, which was usually done outside the house. Many workers have been terminated as their jobs cannot be done from home (e.g., production activates that are done by machines on production plants). Consequently, the purchasing power of a large portion of the economy has been declined, which projected sluggishness in the tourism sector (Guridno and Guridno, 2020).

The coronavirus outbreak has severely affected the transportation and communication businesses. Due to the cancellation of flights, a significant decline in sales and revenue has been found in airlines companies (Hoque et al., 2020). Infectious epidemics significantly reduce international travel and tourism. Such virus propagation can reduce 20$80 \%$ of flights during an epidemic. However, this percentage may vary based on the intensity of virus spread, duration, and pandemic coverage (McKercher \& Chon, 2004). As of February 2021, worldwide COVID-19 cases were elevating as hit by the second wave coronavirus outbreak. Thus, most of the countries maintained restrictions on travel. According to IATA, passengers' air transport is measured in terms of revenue passenger-kilometers (RPKs) which are $74.7 \%$ lower 
in February 2021 than that of February 2019 (a pre-crisis period). Due to the ban on public transport and restriction on cross border movement to protect coronavirus spread, the road transport industry is also affected.

Similarly, the cruising industry has been severely affected by the coronavirus pandemic. Cruise ships are usually used for recreation and tourism. A cruise ship was quarantined by a coronavirus pandemic in February 2020, which changed people's perception of cruising.

The adverse effects of coronavirus in the hotel and restaurant business are indescribable. Tourists who have booked hotels or resorts at various holiday destinations have canceled their bookings because those areas are plagued by pandemics. In many tourist areas, hotel rooms are empty, and restaurants have no customers. Owners are laying off workers to minimize costs. Although limited tourism was introduced in some areas in late 2020, the recent second wave hit of the COVID-19 outbreak causes hotels, resorts, and restaurants of tourist destinations to face severe loss of profit.

However, this COVID-19 pandemic can bring many changes in the tourism industry. A variety of behavioral changes in tourists due to the coronavirus pandemic are expected to be noticed later. Tourists will give priority to health care, social distance, and so on when choosing a tourist destination. Instead of visiting popular tourist destinations, tourists may prefer tourist spots with relatively fewer crowds. Domestic tourism or proximity tourism will be more preferable to tourists than international tourism. Lockdowns imposed on tourist destinations due to the coronavirus pandemic could bring about positive changes in some cases. Nature will get the time to reset the whole system. The sea beaches, rivers, jungles, hills will have time to return to their own natural form. It is a conviction that the world's tourism industry will rise again after overcoming the thorny path of this pandemic.

\section{Recovery of the tourism industry}

The Corona pandemic has caused irreparable damage to the tourism industry. The world's tourism industry has not seen such a catastrophe in the last few decades. The normal lifestyle and mobility of the people are severely disrupted. Along with that, all stakeholders of the tourism and hospitality industry have been suffering to survive. COVID-19 pandemic has affected both the demand side (tourists' perception of health, psychological and social risk) and supply-side (liquidity crisis, job losses, mobility restriction, etc.) of the tourism industry (Matiza, 2020). It has been more than a year of the pandemic, but the world is still failing to find a way out. The tourism industry around the world has already taken several initiatives to recover from the current situation. To prevent the spread of infection, social distancing, avoiding crowd, domestic and international travel restrictions, and quarantine obligations have been imposed. (Ryu et al., 2020). But such restrictions may reduce the capacity of the travel, tourism, and hospitality industries. For example, it is difficult to provide restaurant service without intimate operation. Thus, the removal of such restrictions will be a prerequisite for tourism recovery (Hall et al., 2020). Initiatives should be taken to recover small-scale local restaurants, hotels, tour operators, and VFR tourism may be allowed in accordingly. Tourism can be opened in those areas where maintaining social distancing is possible, such as parks, nature tourism, business tourism, etc. However, senior tourism will still be discouraged (Liu et al., 2020).

The role of government is crucial in post-COVID-19 crisis recovery. Though the government will work for the overall economic recovery, special importance should be given to the tourism industry. The government can provide financial stimulus packages or subsidies to the tourism businesses (Ritchie and Jiang, 2019). Government can also offer fiscal relief through loans, tax holiday or guarantee schemes, low rate loans, temporary VAT reduction, etc. For example, European Commission has accumulated a fund of 37 billion EUR called the 'Coronavirus Response Investment Initiative' to aid small businesses (European Commission, 2020). Moreover, the government has to take the initiative for destination marketing and promotion through utilizing diplomacy channels and international communication channels. Government can also play a vital role in re-ensuring tourist confidence and changing tourist perception (Carlsen and Hughes, 2008; Cooper, 2005; Gu and Wall, 2006).

Usually, tourists feel less risk in domestic tourism than international (Moreno-Luna et al., 2021) which is referred to as 'home is safer than abroad' bias (Wolff et al., 2019). Restarting tourism domestically will be a better option for most countries. Hence domestic tourism promotion campaigns may be launched to encourage domestic tourists (Hall et al., 2020). To promote the demand for domestic tourism, regulatory authorities can offer citizens incentives who spend their holiday within their own country, such as tourism vouchers (OEDC report, 2020). The resumption of such domestic tourism will not only help to revive the local tourism industry but also will help to change the potential inbound tourists' perception of risk (Moreno-Luna et al., 2021). Higgins Desbiolles (2020) and Baum and Hai (2020) forecasted that the pure joy of travel for tourists and gainful employment opportunities for tourism and hospitality workers would hardly recommence in the near-immediate future. As a result, during and after the COVID-19 pandemic, domestic tourism will be most effective (Haywood, 2020). Though in most cases, domestic tourism is limited to VRF tourism, it is expected that leisure tourism will restart soon (Baum \& Hai, 2020). Under this circumstance, 'tourism bubbles' will be an effective way to move forward (Mostafanezhad et al., 2020). Tourism bubbles, also known as travel corridors or corona corridors, are an agreement between two or more countries to open their borders for tourism purposes, and tourists are obligated to follow strict quarantine.

The crowd and social distancing are major issues in the tourism sector during and after the pandemic. Tourists who have 
been confined to their homes for a long time due to lockdowns will prefer less crowded tourist destinations, and they will also look for facilities to practice social distancing (Seraphin \& Dosquet, 2020). Therefore, the interaction between tourists and hospitality workers must be limited. Furthermore, the role of local communities in post-COVID-19 tourism is also significant. A Community-based tourism framework is needed to be implanted to reshape the overall tourism industry spectrum, including changing the attitude of both tourists and hosts (Tremblay-Huet, 2020).

Proper dissemination of reliable, timely, and persuasive information is also vital for the recovery of the devastated tourism industry. COVID-19 pandemic has drastically changed tourist behavior, and within this context, the provision of pertinent information is crucial (Rodri'guez-Morales et al., 2020). Communication of information can strongly influence tourists' risk perception and behavior. Properly planned marketing communication can draw attention, build awareness, as well as create trust and loyalty for tourists (Aliperti and Cruz, 2019). After the earthquake in Japan in 2011 caused the Fukushima disaster, the marketing campaign from the Japanese tourism authority successfully constricted the perceived risk of tourists (Chew and Jahari, 2014). Ecotourism can be promoted using a targeted marketing approach. As there are some restrictions due to health and safety issues, specific segments or niches may be targeted instead of mass tourism. Thus, tour operators might target individuals or small groups and promote diverse tour destinations (OEDC report, 2020). Moreover, tourism organizations may enter in new markets by promoting the safety of the destination, food safety, health care facilities, etc. (Chew and Jahari, 2014).

Fuchs and Reichel (2011) found that tourists' information searching increases when there is a greater perceived risk associated with travel. Huynh (2020) found a correlation between the risk of COVID-19 virus in tourism and tourists' information search on social media. Social media can be a stepping stone that will help tourists minimize risk and encourage them to participate in domestic or international tourism again. In the post-COVID-19 era, the credibility of information will be an effective way to mitigate perceived psychological, physical, and social risks (Aliperti and Cruz, 2019). Social media profiles of destinations, news, documentaries, websites, and advertisements will meet tourists' information needs for tourism decision-making in post-crisis situations (Chew and Jahari, 2014; Kapuściński and Richards, 2016; Zhai et al., 2019). Moreover, digital word-of-mouth spread on social media by the local tourist will also mitigate the perceived risk of international tourists.

COVID-19 pandemic has changed tourists' perception of tourism safety (Yu et al., 2020). Under this situation, regaining tourists' confidence in travel and hospitality is a vital issue. Restoring tourists' confidence will reduce their perception of risk, which is essential for the revival of the halted tourism industry (Assaf \& Scuderi, 2020). During the post-pandemic situation, ensuring the trust of tourists is also significant. The safety policy of destinations and the hospitality sector can play a dominant role in ensuring trust. For example, limited hotel reservations and limit on arrival tourists have been introduced in Hawaii to minimize the chance of further infection (McAvoy, 2020). In Singapore, tourism organizations are rebuilding the trust of tourists by establishing new cleaning standards which are audited by a third party (Singapore Tourism Board, 2020).

Technology may be one of the main tools in the recovery of the post-pandemic tourism industry. Technology has helped businesses and the general public in various ways during this pandemic, and the use of technology by the mass has also been boosted. In the tourism business, robotics technology, automation, or the use of artificial intelligence may reduce cost and provide flexibility. Technology will also facilitate ensuring social distancing, contactless service delivery in hotels and restaurants (Assaf \& Scuderi, 2020; Thomas \& Chopra, 2020). Mobile apps or other technological solutions might be used for screening and contact tracing (Hall et al., 2020).

Moreover, a digital vaccine passport will enable free-flowing travel between countries. During the COVID-19 pandemic, the transportation and aviation sectors have faced severe losses. Due to elongated lockdowns and border closure, transportation businesses are going through a serious financial crisis. Thus, opening borders by maintaining flexible immigration policies and resuming transportation mobility will facilitate the tourism industry's recovery. Tourism authorities around must also focus on innovation and investment in the tourism sector for its rapid recovery. It is indeed that the pandemic will significantly change the tourist behavior and overall tourism scenario. Under this circumstance, innovative tourism opportunities (solo tourism, travel bubbles, flexible travel, etc.) will re-attract the tourist. Moreover, infrastructural change and development are needed in a post-COVID-19 era of tourism. Public-private partnership in this regard will work fair.

\section{CONCLUSION}

The tourism industry continues to make a huge contribution to the world economy over the years. However, various disasters have occurred in the tourism industry at different times. In the past, several pandemics have affected the tourism industry in various ways, but the damage caused by the COVID-19 pandemic can be considered the most severe. This study has used secondary data to articulate the damage in the tourism and hospitality industry caused by the COVID-19 pandemic and find a way out. After a thorough analysis of secondary data, this study revealed that government should play a vital role in the recovery process.

Along with that role of marketing activities, promotion, social media is also crucial. Tourism organizations are needed to work to improve tourists' confidence and trust. The tourism authorities must focus on domestic travel and tourism, which 
International Journal of Tourism \& Hospitality Review elSSN: 2395-7654, Vol 8, No 2, 2021, pp 01-07 https://doi.org/10.18510/ijthr.2021.821

might change international tourists' perceptions. Vaccination, social distancing, and maintenance of personal hygiene are also important for the revival of the tourism industry.

\section{LIMITATION AND STUDY FORWARD}

This qualitative study is based on secondary data collected from various published online sources. Recovery experiences of the tourism industry from previous pandemics were used to find out a possible recovery plan for the present COVID19 pandemic. However, any qualitative or quantitative study based on primary data will better address the current concern.

\section{REFERENCE}

1. Aliperti, G., \& Cruz, A. M. (2019). Investigating tourists' risk information processing. Annals of Tourism Research, 79, 102803. https://doi.org/10.1016/j.annals.2019.102803

2. Aljazeera (2020, February 16). China coronavirus outbreak: All the latest updates. https://www.aljazeera.c om/new s/2020/02/china-coronavirus-outbreak-latestupdates-200206001100173.html

3. Assaf, A., \& Scuderi, R. (2020). COVID-19 and the recovery of the tourism industry. Tourism Economics, 731733. ttps://doi.org/10.1177/1354816620933712

4. Baum, T., \& Hai, N. T. T. (2020). Hospitality, tourism, human rights and the impact of COVID19. International Journal of Contemporary Hospitality Management, 32(7), 2397-2407. https://doi.org/10.1 108/IJCHM-03-2020-0242

5. CAPA - Centre for Aviation. (2009, April 29). International passenger demand keeps falling, swine flu timing "could not be worse" - IATA. https://centreforaviation.com/analysis/reports/international-passenger-demandkeeps-falling-swine-flu-timing-could-not-be-worse---iata-6882

6. Carlsen, J. C., \& Hughes, M. (2008). Tourism market recovery in the Maldives after the 2004 Indian Ocean tsunami. Journal of Travel \& Tourism Marketing, 23(2-4), 139-149. https://doi.org/10.1300/J073v23n02_11

7. Centers for Disease Control and Prevention (2019, August 2). About MERS. https://www.cdc.gov/coronav irus/mers/about/index.html

8. Chew, E. Y. T., \& Jahari, S. A. (2014). Destination image as a mediator between perceived risks and revisit intention: A case of post-disaster Japan. Tourism Management, 40, 382-393. https://doi.org/10.1016/j.t ourman.2013.07.008

9. Cooper, M. (2017). Japanese tourism and the SARS epidemic of 2003. In Tourism Crises (pp. 129-144). Routledge.

10. Countries where Coronavirus has spread - Worldometer. (n.d.). Worldometer. Retrieved May 3, 2021, from https://www.worldometers.info/coronavirus/countries-where-coronavirus-has-spread/

11. European Commission (2020). Corona Virus-Response Investment-Initiative. Retrieved May 15, 2021, from https://ec.europa.eu/regional_policy/en/newsroom/news/2020/03/30-03-2020-coronavirus-responseinvestmentinitiative-adopted \%20-\%2030\%20March\%202020

12. Fuchs, G., \& Reichel, A. (2011). An exploratory inquiry into destination risk perceptions and risk reduction strategies of first time vs. repeat visitors to a highly volatile destination. Tourism Management, 32(2), 266-276. https://doi.org/10.1016/j.tourman.2010.01.012

13. Gu, H., \& Wall, G. (2006). Sars in China: Tourism impacts and market rejuvenation. Tourism Analysis, 11(6), 367-379. https://doi.org/10.3727/108354206781040731

14. Guridno, E., \& Guridno, A. (2020). COVID-19 Impact: Indonesia Tourism in New Normal Era. International Journal of Management and Humanities (IJMH), 4(11), 31-34. https://doi.org/10.35940/ijmh.K1049.0741120

15. Hall, C. M., Scott, D., \& Gössling, S. (2020). Pandemics, transformations and tourism: be careful what you wish for. Tourism Geographies, 22(3), 577-598. https://doi.org/10.1080/14616688.2020.1759131

16. Haywood, K. M. (2020). A post-COVID future: Tourism community re-imagined and enabled. Tourism Geographies, 22(3), 599-609. https://doi.org/10.1080/14616688.2020.1762120

17. Higgins-Desbiolles, F. (2020). Socialising tourism for social and ecological justice after COVID-19. Tourism Geographies, 22(3), 610-623. https://doi.org/10.1080/14616688.2020.1757748

18. Hoque, A., Shikha, F. A., Hasanat, M. W., Arif, I., \& Hamid, A. B. A. (2020). The effect of Coronavirus (COVID-19) in the tourism industry in China. Asian Journal of Multidisciplinary Studies, 3(1), 52-58.

19. Huynh, T. L. (2020). The COVID-19 risk perception: A survey on socioeconomics and media attention. Econ. Bull, 40(1), 758-764.

20. Kapuściński, G., \& Richards, B. (2016). News framing effects on destination risk perception. Tourism Management, 57, 234-244. https://doi.org/10.1016/j.tourman.2016.06.017

21. Korea Culture and Tourism Institute (2015). Impacts and countermeasures of MERS-CoV in tourism industry. http://www.kcti.re.kr/web/board/boardContentsView.do

22. Liu, C., Zhou, Q., Li, Y., Garner, L. V., Watkins, S. P., Carter, L. J., ... \& Albaiu, D. (2020). Research and development on therapeutic agents and vaccines for COVID-19 and related human coronavirus diseases. ACS Cent Sci., 6(3), 315-331. https://doi.org/10.1021/acscentsci.0c00272 
International Journal of Tourism \& Hospitality Review elSSN: 2395-7654, Vol 8, No 2, 2021, pp 01-07 https://doi.org/10.18510/ijthr.2021.821

23. Long, N. (2020). From social distancing to social containment. Medicine Anthropology Theory, 7(2), $247-260$. https://doi.org/10.17157/mat.7.2.791

24. Matiza, T. (2020). Post-COVID-19 crisis travel behaviour: towards mitigating the effects of perceived risk. Journal of Tourism Futures. https://doi.org/10.1108/JTF-04-2020-0063

25. McAvoy, A. (2020, April 14). Hawaii Looks to Restrict Lodging Reservations to Prevent Visitor Arrivals. Skift. https://skift.com/2020/04/14/hawaii-looks-to-restrict-lodging-reservations-to-prevent-visitor-arrivals/

26. McKercher, B., \& Chon, K. (2004). The over-reaction to SARS and the collapse of Asian tourism. Annals of Tourism Research, 31(3), 716-719. https://doi.org/10.1016/j.annals.2003.11.002

27. Menegaki, A. N. (2020). Hedging Feasibility Perspectives against the COVID-19 for the International Tourism Sector. https://doi.org/10.20944/preprints202004.0536.v1

28. Mitigating the impact of COVID-19 on tourism and supporting recovery. (2020, December 16). OEDC iLibrary. https://www.oecd-ilibrary.org/industry-and-services/mitigating-the-impact-of-covid-19-on-tourismand-supporting-recovery 47045bae-en

29. Monterrubio, J. C. (2010). Short-term economic impacts of influenza A (H1N1) and government reaction on the Mexican tourism industry: an analysis of the media. International Journal of Tourism Policy, 3(1), 1-15. https://doi.org/10.1504/IJTP.2010.031599

30. Moreno-Luna, L., Robina-Ramírez, R., Sánchez, M. S. O., \& Castro-Serrano, J. (2021). Tourism and Sustainability in Times of COVID-19: The Case of Spain. International Journal of Environmental Research and Public Health, 18(4), 1859. https://doi.org/10.3390/ijerph18041859

31. Mostafanezhad, M., Cheer, J. M., \& Sin, H. L. (2020). Geopolitical anxieties of tourism:(Im) mobilities of the COVID-19 pandemic. Dialogues in Human Geography, 10(2), 182-186. https://doi.org/10.1177/204 3820620934206

32. Pine, R., \& McKercher, B. (2004). The impact of SARS on Hong Kong's tourism industry. International Journal of Contemporary Hospitality Management, 16(9), 139-143. https://doi.org/10.1108/09596 110410520034

33. Ritchie, B. W., \& Jiang, Y. (2019). A review of research on tourism risk, crisis and disaster management: Launching the annals of tourism research curated collection on tourism risk, crisis and disaster management. Annals of Tourism Research, 79, 102812. https://doi.org/10.1016/j.annals.2019.102812

34. Rodríguez-Morales, A. J., MacGregor, K., Kanagarajah, S., Patel, D., \& Schlagenhauf, P. (2020). Going global-Travel and the 2019 novel coronavirus. Travel medicine and infectious disease, 33, 101578. https://doi.org/10.1016/j.tmaid.2020.101578

35. Ryu, S., Gao, H., Wong, J. Y., Shiu, E. Y., Xiao, J., Fong, M. W., \& Cowling, B. J. (2020). Nonpharmaceutical measures for pandemic influenza in nonhealthcare settings - international travel-related measures. Emerging infectious diseases, 26(5), 961. https://doi.org/10.3201/eid2605.190993

36. Schulze, W., \& Wansink, B. (2012). Toxics, toyotas, and terrorism: the behavioral economics of fear and stigma. Risk Analysis: An International Journal,32(4), 678-694. https://doi.org/10.1111/j.15396924.2011.01748.x

37. Seraphin, H., \& Dosquet, F. (2020). Mountain tourism and second home tourism as post COVID-19 lockdown placebo? Worldwide Hospitality and Tourism Themes. https://doi.org/10.1108/WHATT-05-2020-0027

38. SG Clean Quality Mark Extended to Tourism and Lifestyle Businesses as part of Nationwide Efforts to Uplift Sanitation and Hygiene | STB. (2020, March 12). Singapore Tourism Board. https://www.stb.gov.sg/content/stb/en/media-centre/media-releases/sg-clean-qualitymarkextendedtotourismand life stylebusiness esaspar.html.html

39. Sheller, M. (2020). Some thoughts on what comes after a mobility shock. Critical Automobility Studies Lab.

40. Statista. (2021, February 4). Travel and tourism: share of GDP worldwide 2000-2019. https://www.statista.c om/statistics/1099933/travel-and-tourism-share-of-gdp/

41. Thomas, A., \& Chopra, M. (2020). On how big data revolutionizes knowledge management. In Digital transformation in business and society (pp. 39-60). Palgrave Macmillan, Cham. https://doi.org/10.1007/978-3030-08277-2_3

42. Travel \& Tourism Economic Impact | World Travel \& Tourism Council (WTTC). (n.d.). World Travel and Tourism Council. Retrieved April 5, 2021, from https://wttc.org/Research/Economic-Impact\#:\%7E:text=In\%2 02019\%2C\%20the\%20Travel\%20\%26\%20Tourism,to\%20334\%20million\%20in\%202019

43. Tremblay-Huet, S. (2020). COVID-19 leads to a new context for the "right to tourism": A reset of tourists' perspectives on space appropriation is needed. Tourism Geographies, 22(3), 720-723. https://doi.org/10.1080/ $\underline{14616688.2020 .1759136}$

44. Wilder-Smith, A. (2006). The severe acute respiratory syndrome: impact on travel and tourism. Travel medicine and infectious disease, 4(2), 53-60. https://doi.org/10.1016/j.tmaid.2005.04.004

45. Wolff, K., Larsen, S., \& Øgaard, T. (2019). How to define and measure risk perceptions. Annals of Tourism Research, 79, 102759. https://doi.org/10.1016/j.annals.2019.102759

46. Yu, F., Du, L., Ojcius, D. M., Pan, C., \& Jiang, S. (2020). Measures for diagnosing and treating infections by a novel coronavirus responsible for a pneumonia outbreak originating in Wuhan, China. Microbes and infection, 22(2), 74-79. https://doi.org/10.1016/j.micinf.2020.01.003 
International Journal of Tourism \& Hospitality Review elSSN: 2395-7654, Vol 8, No 2, 2021, pp 01-07 https://doi.org/10.18510/ijthr.2021.821

47. Zhai, X., Zhong, D., \& Luo, Q. (2019). Turn it around in crisis communication: An ABM approach. Annals of Tourism Research, 79, 102807. https://doi.org/10.1016/j.annals.2019.102807 